\title{
O CAMPO POLÍTICO PARANAENSE NO CONTEXTO DO GOLPE DE 1964 E SUAS LUTAS POLÍTICAS, de Natália Cristina Granato ${ }^{1}$
}

Jaderson Goulart Jr²

- Enviado em 13/05/2017

- Aprovado em 28/06/2017

Quando finalmente o Brasil vivenciou a urbanização e o êxodo rural, as classes mais exploradas da sociedade perceberam que tinham poder para mudar a sua situação de vida. $\mathrm{Na}$ medida em que os trabalhadores buscaram maiores direitos, as classes média e alta tremeram diante de tal força e, para freia-los, instituiu um golpe de estado com a premissa de "acabar com o caos social".

Em sua dissertação, Natália C. Granato busca reavivar o período histórico do Golpe Civil Militar, suas forças impulsivas e os efeitos refletidos não só na sociedade e política brasileira, mas, principalmente, na paranaense. O principal objetivo é analisar os impactos do golpe na política local e a interação entre os atores políticos na respectiva conjuntura.

No primeiro capítulo, a autora faz uma revisão literária de trabalhos importantes para entender o ambiente social da época com Wanderley Guilherme dos Santos, Caio Navarro de Toledo, René Armand Dreifuss e Guillermo O’Donnel. Para compreender a tradição autoritária no Brasil são citados Oliveira Vianna e Francisco Campos. É exposta também, de forma sucinta, a história das Forças Armadas, principalmente no âmbito anticomunista e conservador. Depois, são

\footnotetext{
${ }^{1}$ Dissertação de Mestrado de Natália Cristina Granato defendida em 2016 no Programa de Pós-Graduação em Sociologia da UFPR, sob orientação do Prof. Dr. Ricardo Costa de Oliveira. A versão completa está disponível no Acervo Digital da UFPR http://acervodigital.ufpr.br/handle/1884/43268.
}

2 Graduando em Ciências Econômicas, na Universidade Federal do Paraná. Endereço eletrônico:jaderson.junior@uol.com.br 
apresentadas as contribuições teóricas de Pierre Bourdieu para entender o campo político paranaense e de Ricardo Costa de Oliveira para entender o conceito sociológico de "família".

O segundo capítulo explica a situação da política desde a queda do Estado Novo de Getúlio até os dois primeiros Atos Institucionais e as mudanças socioeconômicas no Paraná entre 1945 e 1964, junto com a sua influência na esfera política. O terceiro elucida quais eram os partidos políticos nacionais durante o período e suas respectivas seções paranaenses, pois estes seriam subcampos dentro do campo político.

O quarto e o quinto capítulo trabalham as lutas políticas e as eleições no Paraná antes do golpe, tanto a dinâmica partidária quanto entre os agentes nos subcampos políticos após 1964 . O foco é também o processo de transição e as consequências institucionais. No sexto e último capítulo a pesquisadora esmiúça dados das eleições de deputados e senadores buscando traçar as relações entre eles e os militares, investigando o impacto do Segundo Ato Institucional.

De maneira geral, Granato mostra a convergência dos aspectos de dimensões nacionais no plano sociopolítico paranaense. Enquanto no Brasil “(...) a burguesia e o capital transnacionalizado intensificaram suas organizações de classe pelo intermédio do IPES e do IBAD, combatendo as reformas de base e o governo Goulart (...)" (GRANATO, 2016, p.55), no Paraná, os grandes cafeicultores e industriais também se colocavam contra as decisões de Jango, sendo representados pelo partido UDN.

Da mesma forma que se propagava um discurso anticomunista pelo território nacional, no Paraná Ney Braga, que foi aluno de Castelo Branco na Escola Superior de Guerra, como Governador, promoveu a propaganda de que a melhor forma de combate era o desenvolvimento, onde não havia espaço para mobilizações sociais de "desordem" e "subersão". Seu esforço foi tamanho que entrava em conflito com alas não declaradamente anticomunistas dentro do seu partido, o PDC.

A autora evidência também que, no primeiro momento, a principal estratégia dos deputados e senadores era de não impedir os avanços do Governo Militar, já que isso colocaria em xeque os capitais políticos acumulados. Então, muitos se autodenominaram "defensores da revolução", enquanto os contrários se abstinham. Mas, 
“[...] na medida em que o projeto militar se desenrola no país, alguns políticos que eram totalmente favoráveis aos atos da 'revolução' vão se desvinculando da mesma, na medida em que vêem ameaçadas as suas respectivas carreiras políticas, uma vez que alguns dos capitais acumulados ao longo das suas trajetórias perderam força com as novas regras do jogo [...]". (GRANATO, 2016, p. 168)

Então, o Ato Institucional $n^{\circ} 2$ eliminou todos os partidos políticos, mas para garantir aparência democrática, apenas dois partidos funcionariam no país: o MDB (Movimento Democrático Brasileiro)e a ARENA (Aliança Nacional Renovadora). Uma anedota da época remonta ao caráter figurativo do sistema bipartidário: "o partido do sim" e o "partido do sim, senhor", respectivamente. No Paraná, Ney Braga, agora Ministro da Agricultura do governo Castelo Branco, foi o grande pai da ARENA, reunindo políticos das mais diferentes áreas. Já o MDB foi organizado pela maioria dos ex-petebistas que, mesmo tendo seu partido sofrido uma grande investida dos militares, não foram expurgados pelo Al 1.

Nas eleições de 1966 a supremacia da ARENA em relação ao MDB foi evidente: na Câmara Federal 20 cadeiras eram da ARENA, enquanto apenas cinco eram emedebistas. Na Assembleia Legislativa a ARENA teve 37 deputados estaduais eleitos contra oito do MDB. Desses oito, quatro foram petebistas e, mais tarde, três seriam cassados pelo Al5.

Importante ressaltar que houve grande aderência dos políticos paranaenses à ARENA, onde misturavam-se udenistas (UDN), pedecistas(PDC), peteenistas (PTN) e até mesmo petecebistas (PTB). Isso fez com que o partido se fragmentasse e, com as disputas políticas internas, faltava unidade, concordância e coerência.

Com o $\mathrm{Al} 5$, os políticos perderam mais poder ainda e, como dito anteriormente, começaram a se organizar na Frente Ampla, um movimento de oposição ao Governo Militar. Nesse momento, muitos deputados e senadores foram cassados, até mesmo os que apoiaram a revolução. Mas no dia 5 de abril de 1968, o presidente Costa e Silva proibiu as atividades do movimento.

Em síntese, o trabalho apresenta um grande esforço para elucidar a conjuntura da época do Golpe Militar no Paraná. Tratando desde as trajetórias e relações familiares de grandes agentes políticos até os movimentos institucionais nacionais, Natália Granato concebe uma obra de grande contribuição histórico-política. 